\title{
Type 2 diabetes-related variants influence the risk of developing multiple myeloma: results from the IMMEnSE consortium
}

\author{
Rafael Ríos ${ }^{1,2, *}$, Carmen Belén Lupiañez ${ }^{1,2, *}$, Daniele Campa ${ }^{3,4}$, Alessandro Martino ${ }^{3}$, \\ Joaquin Martínez-López ${ }^{5}$, Manuel Martínez-Bueno ${ }^{6}$, Judit Varkonyi ${ }^{7}$, \\ Ramón García-Sanz ${ }^{8}$, Krzysztof Jamroziak ${ }^{9}$, Charles Dumontet $^{10}$, \\ Andrés Jerez Cayuela", Marzena Wętek ${ }^{12}$, Stephano Landi ${ }^{4}$, Anna Maria Rossi ${ }^{4}$, \\ Fabienne Lesueur ${ }^{13}$, Rui Manuel Reis ${ }^{14,15,16}$, Victor Moreno ${ }^{17}$, Herlander Marques ${ }^{14,15}$, \\ Artur Jurczyszyn ${ }^{18}$, Vibeke Andersen ${ }^{19,20}$, Ulla Vogel ${ }^{20}$, Gabriele Buda ${ }^{21}$, \\ Enrico Orciuolo ${ }^{21}$, Svend E H Jacobsen ${ }^{22}$, Mario Petrini ${ }^{21}$, Annette J Vangsted ${ }^{23}$, \\ Federica Gemignani ${ }^{4}$, Federico Canzian ${ }^{3}$, Manuel Jurado ${ }^{1,2}$ and Juan Sainz ${ }^{1,2}$ \\ ${ }^{1}$ Genomic Oncology Area, GENYO, Centre for Genomics and Oncological Research: Pfizer/ \\ University of Granada/Andalusian Regional Government, PTS, Granada, 18016 Granada, Spain \\ ${ }^{2}$ Hematology Department, Virgen de las Nieves University Hospital, Granada, Spain \\ ${ }^{3}$ Genomic Epidemiology Group, German Cancer Research Center (DKFZ), Heidelberg, Germany \\ ${ }^{4}$ Department of Biology, University of Pisa, Pisa, Italy \\ ${ }^{5}$ Department of Hematology, Hospital Universitario Doce de Octubre, Madrid, Spain \\ ${ }^{6}$ Area of Genomic Medicine, GENYO, Centre for Genomics and Oncological Research: Pfizer/ \\ University of Granada/Andalusian Regional Government, PTS Granada, Granada, Spain \\ ${ }^{7}$ Semmelweis University, Budapest, Hungary \\ ${ }^{8}$ Haematology Department, University Hospital of Salamanca and IBSAL, Salamanca, Spain \\ ${ }^{9}$ Medical University of Lodz, Lodz, Poland \\ ${ }^{10}$ INSERM UMR 1052/CNRS 5286, Université Claude Bernard Lyon I, Lyon, France \\ ${ }^{11}$ Morales Meseguer General University Hospital, Murcia, Spain \\ ${ }^{12}$ Haematoloy Clinik, Holly Cross Cancer Center, Kielce, Poland \\ ${ }^{13}$ INSERM, U900, Genetic Epidemiology of Cancers team, Institut Curie, Mines ParisTech, Paris, France \\ ${ }^{14}$ Life and Health Sciences Research Institute (ICVS), School of Health Sciences, University of Minho, \\ Braga, Portugal \\ ${ }^{15}$ ICVS/3B's - PT Government Associate Laboratory, Braga/Guimarães, Portugal \\ ${ }^{16}$ Molecular Oncology Research Center, Barretos Cancer Hospital, Barretos, Brazi \\ ${ }^{17}$ IDIBELL - Catalan Institute of Oncology, University of Barcelona, Barcelona 08907, Spain \\ ${ }^{18}$ Department of Hematology, Cracow University Hospital, Cracow, Poland \\ ${ }^{19}$ Organ Center, Hospital of Southern Jutland, DK-6200 Aabenraa, Denmark \\ ${ }^{20}$ Faculty of Health Sciences, Institute of Regional Health Research, University of Southern Denmark, \\ DK-5000 Odense C, Denmark \\ ${ }^{21}$ UO Hematology, Department of Internal and Experimental Medicine, University of Pisa, Pisa, Italy \\ ${ }^{22}$ Clinic of Biochemistry and Immunology, Laboratory Center, Hospital of Southern Jutland, \\ Aabenraa, Denmark \\ ${ }^{23}$ Department of Haematology, Rigshospitalet and Roskilde Hospital, Copenhagen University, Copenhagen, \\ Denmark \\ *(R Ríos and C B Lupiañez contributed equally to this work)
}

Correspondence should be addressed to J Sainz Email

juan.sainz@genyo.es http://erc.endocrinology-journals.org DOI: 10.1530/ERC-15-0029
(C) 2015 Society for Endocrinology Printed in Great Britain
Published by Bioscientifica Ltd. 


\section{Abstract}

Type 2 diabetes (T2D) has been suggested to be a risk factor for multiple myeloma (MM), but the relationship between the two traits is still not well understood. The aims of this study were to evaluate whether 58 genome-wide-association-studies (GWAS)-identified common variants for T2D influence the risk of developing MM and to determine whether predictive models built with these variants might help to predict the disease risk. We conducted a case-control study including $1420 \mathrm{MM}$ patients and 1858 controls ascertained through the International Multiple Myeloma (IMMEnSE) consortium. Subjects carrying the $K C N Q 1_{\text {rs2237892T }}$ allele or the

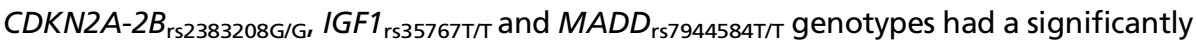
increased risk of $\mathrm{MM}$ (odds ratio $(\mathrm{OR})=1.32-2.13$ ) whereas those carrying the $K C N J 11_{\text {rs5215C, }}$ $K C N J 11_{\text {rs5219T }}$ and THADA $A_{\text {rs7578597C }}$ alleles or the $F T O_{\text {rs8050136A/A }}$ and $L T A_{\text {rs1041981C/C genotypes }}$ showed a significantly decreased risk of developing the disease $(O R=0.76-0.85)$. Interestingly, a prediction model including those T2D-related variants associated with the risk of MM showed a significantly improved discriminatory ability to predict the disease when compared to a model without genetic information (area under the curve $(A \cup C)=0.645$ vs $A U C=0.629 ; P=4.05 \times$ $\left.10^{-06}\right)$. A gender-stratified analysis also revealed a significant gender effect modification for $A D A M 30_{\text {rs2641348 }}$ and $N O T C H 2_{\text {rs } 10923931}$ variants $\left(P_{\text {interaction }}=0.001\right.$ and 0.0004 , respectively). Men carrying the $A D A M 30_{\text {rs } 2641348 \mathrm{C}}$ and $N O T C H 2_{\text {rs } 10923931 T}$ alleles had a significantly decreased risk of $M M$ whereas an opposite but not significant effect was observed in women $\left(O R_{M}=0.71\right.$ and $O R_{M}=0.66$ vs $O R_{W}=1.22$ and $O R_{W}=1.15$, respectively). These results suggest that TD2-related variants may influence the risk of developing MM and their genotyping might help to improve MM risk prediction models.

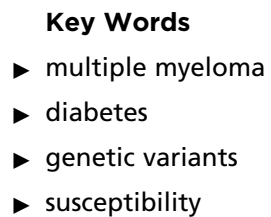

Endocrine-Related Cancer (2015) 22, 545-559

\section{Introduction}

Multiple myeloma (MM) is a plasma-cell neoplasm of complex aetiology that may arise as a result of the interaction between adverse environmental and inherited genetic risk factors (Morgan et al. 2012). Although survival rates for MM have improved dramatically during the last two decades, likely due to the introduction of novel targeted therapies (proteasome inhibitors, immunomodulators and others), the disease outcome still remains poor with a 5-year overall survival rate not higher than 55\% (Kumar et al. 2014).

Age, male gender, African ancestry and monoclonal gammopathy of uncertain significance (MGUS) have been established as major risk factors for MM (Alexander et al. 2007). In addition, exposure to a wide range of toxins as well as type 2 diabetes (T2D) and obesity have been suggested as important mediators of the complex process of myelomagenesis (Alexander et al. 2007, Lope et al. 2008, Wallin \& Larsson 2011). Among these latter preventable factors, T2D has attracted significant attention since it has been consistently identified as a medical condition frequently found in MM patients (Khan et al. 2008, Richardson et al. 2009, Castillo et al. 2012) and it is thought to influence the myelomagenesis through hyperglycaemia and insulin-dependent and -independent mechanisms (Xu et al. 2014). In a recent well-powered meta-analysis, Castillo et al. (2012) observed that T2D was significantly associated with an increased risk of developing the disease (Castillo et al. 2012). This finding concurs with those previously reported in several epidemiological studies that showed a high incidence of T2D among MM patients ranging between 11 and 22\% (Richardson et al. 2006, Badros et al. 2007). In addition, it has been reported that T2D may have a negative impact on MM prognosis (Chiu et al. 2006, Wu et al. 2014) and that the treatment with anti-diabetic drugs may effectively kill MM cells (Wu et al. 2014).

Considering that T2D and MM have strong genetic components and share several biological pathways and markers (Xu et al. 2014) and that T2D-related polymorphisms may influence the risk of developing solid cancer (Folsom et al. 2008, Cheng et al. 2011, Sainz et al. 2012, Ma et al. 2014), we hypothesized that genetic risk factors for T2D may be associated with the risk of developing MM. So far there have not been studies evaluating the impact of diabetogenic variants on the risk of developing hematological cancers. Therefore, we decided to conduct a

Published by Bioscientifica Ltd. 
multi-centre case-control study including $1420 \mathrm{MM}$ patients and 1858 controls to evaluate whether 58 variants convincingly shown to be associated with T2D contribute to the risk of developing MM. We also aimed at determining whether predictive models including T2D-related variants significantly improve the discriminatory ability to predict the risk of MM.

\section{Material and methods}

\section{Study population}

The study population consisted of $1420 \mathrm{MM}$ patients (705 women and 715 men) and 1858 controls (916 women and 942 men) ascertained through the International Multiple Myeloma (IMMEnSE) consortium (Supplementary Table 1, see section on supplementary data given at the end of this article), which has been described in detail elsewhere (Martino et al. 2012). The diagnosis of MM was assigned by physician and fulfilled the International Myeloma Working Group (IMWG) criteria (International Myeloma Working Group 2003). Controls were blood donors or hospitalized subjects with a diagnosis not related to cancer who were recruited in the same geographical area of the cases (Supplementary Table 1). Additional information concerning to the recruitment strategy of controls is shown in the Supplementary Material. The investigation was approved by the ethical committee of each participant institution, functioning according to the third edition of the Guidelines on the Practice of Ethical Committees in Medical Research issued by the Royal College of Physicians of London (www.rcplondon.ac.uk) and all participants gave their written informed consent to participate in the study.

\section{SNP selection and genotyping}

Fifty-eight genome-wide-association-studies (GWAS)-identified variants for T2D were selected to be genotyped in the IMMEnSE consortium population (Table 1 and Supplementary Material). The genotyping of the selected polymorphisms was carried out at GENYO (Centre for Genomics and Oncological Research: Pfizer/University of Granada/ Andalusian Regional Government, Granada, Spain) using KASPar assays (LGC Genomics, Hoddesdon, UK) according to manufacturer's instructions. For internal quality control, $5 \%$ of samples were randomly selected and included as duplicates. Concordance between the original and the duplicate samples for the 58 SNPs was $\geq 99.0 \%$. Call rates for all SNPs were $\geq 90.0 \%$ with the exception of the $W F S 1_{\mathrm{rs} 734312} \mathrm{SNP}$ that was excluded from further analyses.

\section{Statistical analysis}

The Hardy-Weinberg Equilibrium (HWE) tests were performed in the control group by a standard observedexpected $\chi^{2}$ test. Logistic regression analyses were used to assess the effects of the genetic polymorphisms on MM risk using co-dominant, dominant, recessive and log-additive inheritance models. Overall analyses were adjusted for age at diagnosis, gender and country of origin. All analyses were conducted using the statistical software SSPS (version 20.0). Statistical power was calculated using the Quanto vs12.4 (http://biostats.usc.edu/software) assuming a logadditive model.

In order to account for multiple testing, we calculated an adjusted significance level using the $\mathrm{M}_{\text {eff }}$ method (Nyholt 2004), which considers the number of independent marker loci $\left(\mathrm{M}_{\text {effLi }}=55\right)$ but also the number of models of inheritance tested (co-dominant, dominant, recessive and log-additive). Thus, the resulting threshold for the main effect analysis was $0.00022((0.05 / 55) / 4)$ (Supplementary Material). Since a study-wide significance threshold considering all these factors is generally perceived as a 'too conservative' test, we also assessed the magnitude of observed associations between selected SNPs and risk of $\mathrm{MM}$ through a quantile-quantile (QQ) plot generated from the results of the IMMEnSE population. The observed association $P$ values were ranked in order from smallest to largest on the $y$-axis and plotted against the expected results from a theoretical $\sim \chi^{2}$-distribution under the null hypothesis of no association on the $x$-axis. A deviation from the identity line would confirm that the number of corresponding associations is more than expected under the null hypothesis and therefore that these associations are likely to be true associations.

\section{Predictive models and discriminative accuracy}

We also examined the value of T2D-related polymorphisms for prediction of MM using stepwise logistic and Cox regression analyses. We built a prediction model including age and sex and those genetic variants that showed significant associations with $\mathrm{MM}$ in the single-SNP analysis $(P<0.05)$. Then, using $P$ values as a selection criterion, we dropped variables that have the highest $P$ value and we stopped when all variables were significant defined by $P<0.10$. The area under the curve (AUC) of a receiver operating characteristic (ROC) curve analysis was used to assess the discriminative accuracy of this particular model compared with a reference model including age and sex as covariates. A $-2 \log$ likelihood ratio (LR) test

Published by Bioscientifica Ltd. 
Table 1 Selected type-2 diabetes-related SNPs

\begin{tabular}{|c|c|c|c|c|c|c|}
\hline Gene name & dbSNP rs\# & $\begin{array}{l}\text { Nucleotide } \\
\text { substitution }\end{array}$ & $\begin{array}{l}\text { Reference } \\
\text { allele } \\
\text { IMMEnSE }\end{array}$ & $\begin{array}{l}\text { GWAS- } \\
\text { identified risk } \\
\text { allele for T2D }\end{array}$ & $\begin{array}{l}\text { Location/Aa } \\
\text { substitution }\end{array}$ & References \\
\hline ADAM30 & rs2641348 & $T / C^{a}$ & $\mathrm{~T}$ & $\mathrm{C}$ & L359P & $\begin{array}{l}\text { Zeggini et al. (2008) and } \\
\text { Lyssenko et al. (2009) }\end{array}$ \\
\hline ADAMTS9 & rs4607103 & $\mathrm{T} / \mathrm{C}$ & $\mathrm{C}$ & $\mathrm{C}$ & Near gene & $\begin{array}{l}\text { Mohlke et al. (2008), Zeggini et al. (2008) } \\
\text { and Shu et al. (2010) }\end{array}$ \\
\hline$A D C Y 5$ & rs11708067 & $\mathrm{T} / \mathrm{C}$ & $\mathrm{T}$ & $\mathrm{T}$ & Intronic & $\begin{array}{l}\text { Dupuis et al. (2010) and } \\
\text { Saxena et al. (2010) }\end{array}$ \\
\hline$A D R A 2 A$ & rs10885122 & $\mathrm{G} / \mathrm{T}$ & G & G & $\begin{array}{l}\text { Near } \\
\quad \text { ADRA2A }\end{array}$ & Dupuis et al. (2010) \\
\hline $\begin{array}{l}\text { ARAPI, } \\
\quad \text { CENTD2 }\end{array}$ & rs1552224 & $\mathrm{G} / \mathrm{T}$ & $\mathrm{T}$ & $A$ & Near gene & $\begin{array}{l}\text { Voight et al. (2010) and } \\
\text { Nielsen et al. (2011) }\end{array}$ \\
\hline$B C L 11 A$ & rs10490072 & $\mathrm{C} / \mathrm{T}$ & $\mathrm{T}$ & $\mathrm{T}$ & Near gene & Zeggini et al. (2008) \\
\hline$C D C 123$ & rs12779790 & A/G & A & G & Near gene & $\begin{array}{l}\text { Mohlke et al. (2008), Zeggini et al. (2008) } \\
\text { and Shu et al. (2010) }\end{array}$ \\
\hline$C D K A L 1$ & rs7754840 & C/G & G & C & Intronic & $\begin{array}{l}\text { Diabetes Genetics Initiative of Broad } \\
\text { Institute of Harvard and MIT, Lund } \\
\text { University, and Novartis Institutes of } \\
\text { BioMedical Research et al. (2007), } \\
\text { Florez et al. (2007) and } \\
\text { Scott et al. (2007) }\end{array}$ \\
\hline$C D K N 2 A-2 B$ & rs564398 & $\mathrm{T} / \mathrm{C}$ & $\mathrm{T}$ & $\mathrm{T}$ & Near gene & Diabetes Genetics Initiative of Broad \\
\hline$C D K N 2 A-2 B$ & rs10811661 & $\mathrm{T} / \mathrm{C}$ & $\mathrm{T}$ & $\mathrm{T}$ & Near gene & Institute of Harvard and MIT, Lund \\
\hline$C D K N 2 A-2 B$ & rs2383208 & $\mathrm{A} / \mathbf{G}^{\mathrm{b}}$ & $A$ & A & Near gene & $\begin{array}{l}\text { University, and Novartis Institutes of } \\
\text { BioMedical Research et al. (2007), } \\
\text { Scott et al. (2007), Mohlke et al. (2008), } \\
\text { Zeggini et al. (2008), Takeuchi et al. } \\
\text { (2009), Shu et al. (2010) and Yamauchi } \\
\text { et al. (2010) }\end{array}$ \\
\hline COL5A1 & rs4240702 & $\mathrm{C} / \mathrm{T}$ & $\mathrm{C}$ & NS & Intronic & Bouatia-Naji et al. (2009) \\
\hline CRY2 & rs11605924 & $\mathrm{A} / \mathrm{C}$ & $\mathrm{C}$ & A & Intronic & Dupuis et al. (2010) \\
\hline$D C D$ & rs1153188 & $\mathrm{A} / \mathrm{T}$ & A & $A$ & Near gene & Zeggini et al. (2008) \\
\hline EXT2 & rs1113132 & C/G & $\mathrm{C}$ & $\mathrm{C}$ & Intronic & Florez et al. (2007) and Sladek et al. (2007) \\
\hline FADS1 & rs174550 & $\mathrm{C} / \mathrm{T}$ & $A$ & $\mathrm{~T}$ & Intronic & Dupuis et al. (2010) \\
\hline FAM148B & rs11071657 & A/G & $A$ & $A$ & Near gene & $\begin{array}{l}\text { Chambers et al. (2008) and } \\
\text { Dupuis et al. (2010) }\end{array}$ \\
\hline FLJ39370 & rs17044137 & $\mathrm{A} / \mathrm{T}$ & $\mathrm{T}$ & A & Near gene & $\begin{array}{l}\text { Diabetes Genetics Initiative of Broad } \\
\text { Institute of Harvard and MIT, Lund } \\
\text { University, and Novartis Institutes of } \\
\text { BioMedical Research et al. (2007) }\end{array}$ \\
\hline FTO & rs8050136 & $\mathrm{A} / \mathrm{C}^{\mathrm{C}}$ & $\mathrm{C}$ & $A$ & Intronic & $\begin{array}{l}\text { Wellcome Trust Case Control (2007), } \\
\text { Zeggini et al. (2007) and Mohlke et al. } \\
\text { (2008) }\end{array}$ \\
\hline G6PC2 & rs560887 & $\mathrm{G} / \mathrm{A}$ & G & G & Intronic & $\begin{array}{l}\text { Bouatia-Naji et al. (2008, 2009), Chen } \\
\text { et al. (2008), Prokopenko et al. (2009) } \\
\text { and Dupuis et al. (2010) }\end{array}$ \\
\hline GCK & rs1799884 & $\mathrm{G} / \mathrm{A}$ & G & $A$ & Near gene & $\begin{array}{l}\text { Bouatia-Naji et al. (2008, 2009), Chen } \\
\text { et al. (2008), Prokopenko et al. (2009) } \\
\text { and Dupuis et al. (2010) }\end{array}$ \\
\hline$G C K R$ & rs1260326 & $\mathrm{C} / \mathrm{T}$ & $\mathrm{C}$ & $\mathrm{T}$ & L445P & $\begin{array}{l}\text { Bouatia-Naji et al. (2009), Dupuis et al. } \\
\text { (2010) and Saxena et al. (2010) }\end{array}$ \\
\hline HHEX & rs1111875 & $\mathrm{G} / \mathrm{A}$ & $\mathrm{C}$ & $\mathrm{C}$ & Near gene & $\begin{array}{l}\text { Diabetes Genetics Initiative of Broad } \\
\text { Institute of Harvard and MIT, Lund } \\
\text { University, and Novartis Institutes of } \\
\text { BioMedical Research et al. (2007), } \\
\text { Florez et al. (2007), Scott et al. (2007), } \\
\text { Sladek et al. (2007), Wellcome Trust } \\
\text { Case Control (2007), Zeggini et al. } \\
\text { (2007) and Mohlke et al. (2008) }\end{array}$ \\
\hline HMGA2 & rs1531343 & C/G & G & $\mathrm{C}$ & Near gene & $\begin{array}{l}\text { Voight et al. (2010) and } \\
\text { Nielsen et al. (2011) }\end{array}$ \\
\hline
\end{tabular}


Table 1 Continued

\begin{tabular}{|c|c|c|c|c|c|c|}
\hline Gene name & dbSNP rs\# & $\begin{array}{l}\text { Nucleotide } \\
\text { substitution }\end{array}$ & $\begin{array}{l}\text { Reference } \\
\text { allele } \\
\text { IMMEnSE }\end{array}$ & $\begin{array}{l}\text { GWAS- } \\
\text { identified risk } \\
\text { allele for T2D }\end{array}$ & $\begin{array}{l}\text { Location/Aa } \\
\text { substitution }\end{array}$ & References \\
\hline HNF1A, TCF1 & rs7957197 & $A / T$ & $\mathrm{~T}$ & $\mathrm{~T}$ & Intronic & $\begin{array}{l}\text { Voight et al. (2010) and } \\
\text { Nielsen et al. (2011) }\end{array}$ \\
\hline IGF1 & rs35767 & $C / T^{d}$ & C & C & Near gene & $\begin{array}{l}\text { Pechlivanis et al. (2007) and } \\
\text { Dupuis et al. (2010) }\end{array}$ \\
\hline IGF2BP2 & rs4402960 & $\mathrm{G} / \mathrm{T}$ & C & $\mathrm{T}$ & Intronic & $\begin{array}{l}\text { Diabetes Genetics Initiative of Broad } \\
\text { Institute of Harvard and MIT, Lund } \\
\text { University, and Novartis Institutes of } \\
\text { BioMedical Research et al. (2007), } \\
\text { Florez et al. (2007), Scott et al. (2007), } \\
\text { Wellcome Trust Case Control (2007), } \\
\text { Zeggini et al. (2007), Mohlke et al. } \\
\text { (2008) and Shu et al. (2010) }\end{array}$ \\
\hline IL13 & rs20541 & $\mathrm{C} / \mathrm{T}$ & C & $\mathrm{T}$ & R144Q & $\begin{array}{l}\text { Diabetes Genetics Initiative of Broad } \\
\text { Institute of Harvard and MIT, Lund } \\
\text { University, and Novartis Institutes of } \\
\text { BioMedical Research et al. (2007) }\end{array}$ \\
\hline IRS1 & rs2943641 & $\mathrm{C} / \mathrm{T}$ & C & C & Near gene & $\begin{array}{l}\text { Rung et al. (2009), Voight et al. (2010) and } \\
\text { Tang et al. (2013) }\end{array}$ \\
\hline$J A Z F 1$ & rs864745 & A/G & $A$ & $\mathrm{~T}$ & Intronic & Zeggini et al. (2008) and Shu et al. (2010) \\
\hline KCNJ11 & rs5215 & $T / C^{e}$ & $\mathrm{~T}$ & C & V337I & Gloyn et al. (2003), Diabetes Genetics \\
\hline KCNJ11 & rs5219 & $C / T^{f}$ & C & $\mathrm{T}$ & $\mathrm{K} 23 \mathrm{E}$ & $\begin{array}{l}\text { Initiative of Broad Institute of Harvard } \\
\text { and MIT, Lund University, and Novartis } \\
\text { Institutes of BioMedical Research et al. } \\
\text { (2007), Scott et al. (2007), Wellcome } \\
\text { Trust Case Control (2007), Zeggini et al. } \\
\text { (2007), Willer et al. (2007) and Mohlke } \\
\text { et al. (2008) }\end{array}$ \\
\hline KCNQ1 & rs2237897 & $\mathrm{C} / \mathrm{T}$ & $\mathrm{T}$ & C & Intronic & Unoki et al. (2008), Yasuda et al. (2008), \\
\hline KCNQ1 & rs2074196 & $\mathrm{G} / \mathrm{T}$ & G & G & Intronic & Tsai et al. (2010) and Yamauchi et al. \\
\hline KCNQ1 & rs2237892 & $C / T^{g}$ & C & $\mathrm{C}$ & Intronic & (2010) \\
\hline KCNQ1 & rs2237895 & $\mathrm{A} / \mathrm{C}$ & A & C & Intronic & \\
\hline KCNQ1OT1 & rs231362 & $\mathrm{C} / \mathrm{T}$ & C & G & Intronic & $\begin{array}{l}\text { Tsai et al. (2010), Voight et al. (2010) and } \\
\text { Nielsen et al. (2011) }\end{array}$ \\
\hline LTA & rs1041981 & $A / C^{e}$ & A & $A$ & T60N & Hamid et al. (2005) \\
\hline$M A D D$ & rs7944584 & $A / T^{d}$ & A & $A$ & Intronic & Dupuis et al. (2010) \\
\hline MCR4 & rs12970134 & A/G & G & A & Near gene & Chambers et al. (2008) \\
\hline MTNR1B & rs1387153 & $\mathrm{C} / \mathrm{T}$ & C & $\mathrm{T}$ & Near gene & $\begin{array}{l}\text { Bouatia-Naji et al. (2009), Prokopenko } \\
\text { et al. (2009) and Voight et al. (2010) }\end{array}$ \\
\hline NOTCH2 & rs10923931 & $\mathrm{G} / \mathrm{T}^{\mathrm{h}}$ & G & $\mathrm{T}$ & Intronic & $\begin{array}{l}\text { Mohlke et al. (2008) and } \\
\text { Zeggini et al. (2008) }\end{array}$ \\
\hline PKN2 & rs6698181 & $\mathrm{C} / \mathrm{T}$ & C & $\mathrm{T}$ & Intergenic & $\begin{array}{l}\text { Diabetes Genetics Initiative of Broad } \\
\text { Institute of Harvard and MIT, Lund } \\
\text { University, and Novartis Institutes of } \\
\text { BioMedical Research et al. (2007) }\end{array}$ \\
\hline PPARG & rs1801282 & C/G & C & C & P12A & $\begin{array}{l}\text { Altshuler et al. (2000), Diabetes Genetics } \\
\text { Initiative of Broad Institute of Harvard } \\
\text { and MIT, Lund University, and Novartis } \\
\text { Institutes of BioMedical Research et al. } \\
\text { (2007), Scott et al. (2007), Wellcome } \\
\text { Trust Case Control (2007), Willer et al. } \\
\text { (2007), Zeggini et al. (2007, 2008) and } \\
\text { Mohlke et al. (2008) }\end{array}$ \\
\hline PRC1 & rs8042680 & $\mathrm{A} / \mathrm{C}$ & C & A & Intronic & $\begin{array}{l}\text { Voight et al. (2010) and } \\
\text { Nielsen et al. (2011) }\end{array}$ \\
\hline$P R O X 1$ & rs340874 & A/G & $A$ & G & Promoter & Dupuis et al. (2010) \\
\hline RBMS1 & rs7593730 & $\mathrm{C} / \mathrm{T}$ & $\mathrm{C}$ & $\mathrm{T}$ & Intronic & Qi et al. (2010) \\
\hline$S L C 2 A 2$ & rs11920090 & $\mathrm{A} / \mathrm{T}$ & A & $\mathrm{T}$ & Intronic & Dupuis et al. (2010) \\
\hline
\end{tabular}


Table 1 Continued

\begin{tabular}{|c|c|c|c|c|c|c|}
\hline Gene name & dbSNP rs\# & $\begin{array}{l}\text { Nucleotide } \\
\text { substitution }\end{array}$ & $\begin{array}{l}\text { Reference } \\
\text { allele } \\
\text { IMMEnSE }\end{array}$ & $\begin{array}{l}\text { GWAS- } \\
\text { identified risk } \\
\text { allele for T2D }\end{array}$ & $\begin{array}{l}\text { Location/Aa } \\
\text { substitution }\end{array}$ & References \\
\hline SLC30A8 & rs13266634 & $\mathrm{C} / \mathrm{T}$ & C & C & R325W & $\begin{array}{l}\text { Diabetes Genetics Initiative of Broad } \\
\text { Institute of Harvard and MIT, Lund } \\
\text { University, and Novartis Institutes of } \\
\text { BioMedical Research et al. (2007), } \\
\text { Florez et al. (2007), Scott et al. (2007), } \\
\text { Sladek et al. (2007), Steinthorsdottir } \\
\text { et al. (2007), Wellcome Trust Case } \\
\text { Control (2007), Zeggini et al. (2007), } \\
\text { Mohlke et al. (2008), Dupuis et al. } \\
\text { (2010) and Shu et al. (2010) }\end{array}$ \\
\hline TCF2 & rs7501939 & $\mathrm{C} / \mathrm{T}$ & C & C & Intronic & $\begin{array}{l}\text { Gudmundsson et al. (2007) and Sandhu } \\
\text { et al. (2007) }\end{array}$ \\
\hline TCF7L2 & rs7903146 & $\mathrm{C} / \mathrm{T}$ & C & $\mathrm{T}$ & Intronic & Grant et al. (2006), Scott et al. (2006), \\
\hline TCF7L2 & rs12255372 & $\mathrm{G} / \mathrm{T}$ & G & $\mathrm{T}$ & Intronic & $\begin{array}{l}\text { Diabetes Genetics Initiative of Broad } \\
\text { Institute of Harvard and MIT, Lund } \\
\text { University, and Novartis Institutes of } \\
\text { BioMedical Research et al. (2007), } \\
\text { Florez et al. (2007), Scott et al. (2007), } \\
\text { Sladek et al. (2007), Steinthorsdottir } \\
\text { et al. (2007), Wellcome Trust Case } \\
\text { Control (2007), Zeggini et al. (2007), } \\
\text { Mohlke et al. (2008), Dupuis et al. } \\
\text { (2010) and Saxena et al. (2010) }\end{array}$ \\
\hline THADA & rs7578597 & $T / C^{e}$ & $\mathrm{~T}$ & $\mathrm{~T}$ & T1187A & Zeggini et al. (2008) \\
\hline TP53INP1 & rs896854 & A/G & G & G & Intronic & $\begin{array}{l}\text { Voight et al. (2010) and } \\
\text { Nielsen et al. (2011) }\end{array}$ \\
\hline TSPAN8 & rs7961581 & $\mathrm{C} / \mathrm{T}$ & $\mathrm{T}$ & C & Near gene & Grarup et al. (2008) \\
\hline VEGFA & rs9472138 & $\mathrm{C} / \mathrm{T}$ & C & $\mathrm{T}$ & Near gene & Zeggini et al. (2008) \\
\hline WFS1 & rs734312 & A/G & $A$ & NS & H611R & Sandhu et al. (2007) \\
\hline WFS1 & rs10010131 & A/G & G & G & Intronic & Sandhu et al. (2007) \\
\hline
\end{tabular}

NS, not specified; Aa, aminoacid; GWAS, genome-wide association studies. Effect allele in bold and underlined.

${ }^{a} \mathrm{C}$ allele was associated with a decreased risk of MM in men whereas an opposite effect was detected in women

${ }^{\mathrm{b}} \mathrm{G}$ allele was associated with an increased risk of developing MM.

${ }^{\mathrm{C}} \mathrm{A} / \mathrm{A}$ genotype was associated with a decreased risk of MM (recessive model).

${ }^{\mathrm{d}} \mathrm{T} / \mathrm{T}$ genotype was associated with a decreased risk of MM (recessive model).

${ }^{\mathrm{e}} \mathrm{C}$ allele was associated with a decreased risk of MM.

${ }^{\mathrm{f}} \mathrm{T}$ allele was associated with an decreased risk of MM.

${ }^{9} \mathrm{~T}$ allele was associated with an increased risk of MM.

${ }^{\mathrm{h}} \mathrm{T}$ allele was associated with a decreased risk of MM in men whereas an opposite effect was detected in women.

was used to determine whether the predictive model including genetic information fitted significantly better the data compared to the reference model. Although the addition of genetic variables to the reference model will almost always make the model fit better, the LR test allowed us to confirm whether the difference in model fit between both models was statistically significant. Besides this suggestive analysis, we also ran a randomization test to confirm whether the improved predictive ability of the model including genetic variants significantly associated with MM was consistent after 10000 iterations. We compared our full predictive model including significant SNPs, age and gender ('original' model) with 10000 'randomized' models in which the effect of SNPs on MM risk was neutralized by reassigning randomly all genotypes (null distribution; Supplementary Material). Subsequently, we calculated an empirical $P_{\text {iterations-value by }}$ dividing the number of times in which the 'randomized' AUC value was equal or greater than the 'original' AUC value by the number of iterations. Then, we could also calculate the $Z$ score and $P_{Z \text { score-value for the original AUC }}$ using the 'randomized' AUC average of these 10000 iterations and their s.D. All analyses were performed using R software (http://www.r-project.org/).

\section{Gender-specific association analysis}

We also evaluate gender-specific associations of selected SNPs with MM risk. Logistic regression analyses were corrected for age and country of origin. Of note, to

Published by Bioscientifica Ltd 
evaluate whether a different gender distribution across populations within the IMMEnSE consortium could be responsible for the gender effect modification observed for certain SNPs, we also assessed heterogeneity and index $I^{2}$ statistic using Cochran's $\chi^{2}$ based $\mathrm{Q}$ statistic test (Lau et al. 1997). Heterogeneity was considered significant when $P<0.1$.

\section{Results}

\section{Overall associations of selected SNPs with MM risk}

All SNPs were in HWE $(P>0.001)$ with the exception of the

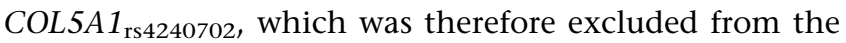
statistical analyses. Logistic regression analysis showed that carriers of the $K C N Q 1_{\text {rs2237892T }}$ allele or the $C D K N 2 A$ $2 B_{\mathrm{rs} 2383208 \mathrm{G} / \mathrm{G}}, I G F 1_{\mathrm{rs} 35767 \mathrm{~T} / \mathrm{T}}$ and $M A D D_{\mathrm{rs} 7944584 \mathrm{~T} / \mathrm{T}}$ genotypes had an increased risk of $\mathrm{MM}$ (odds ratio $(\mathrm{OR})=1.32$, 95\% CI 1.01-1.71, $P=0.039$; OR $=1.86,95 \%$ CI 1.12-3.11, $P=0.016 ; \mathrm{OR}=2.13,95 \%$ CI $1.35-3.37, P=0.0012$ and $\mathrm{OR}=1.33,95 \% \mathrm{CI} 1.06-1.67, P=0.014$, respectively) whereas those harbouring the $K C N J 11_{\text {rs } 5215 C}$, $K C N J 11_{\text {rs5219T }}$ and THADA $A_{\text {rs7578597C }}$ alleles or the $F T O_{\mathrm{rs} 8050136 \mathrm{~A} / \mathrm{A}}$ and $L T A_{\mathrm{rs} 1041981 \mathrm{C} / \mathrm{C}}$ genotypes showed a decreased risk for the disease $(\mathrm{OR}=0.85,95 \%$ CI 0.73 $0.99, P=0.038 ; \mathrm{OR}=0.84,95 \%$ CI $0.72-0.99, P=0.034$; $\mathrm{OR}=0.81,95 \%$ CI $0.68-0.98, P=0.032 ; \mathrm{OR}=0.78,95 \% \mathrm{CI}$ $0.64-0.95, P=0.013$ and $\mathrm{OR}=0.76,95 \%$ CI $0.58-0.99$, $P=0.042$, respectively; Table 2 ). When we corrected for multiple testing (with a threshold of $P=0.00022$ ), none of the reported associations remained statistically significant. The strongest association observed was for the $I G F 1_{\mathrm{rs} 35767} \mathrm{SNP}$ with an increased risk of developing $\mathrm{MM}(\mathrm{OR}=2.13,95 \% \mathrm{CI} 1.35-3.37, P=0.0012)$. In spite of these results, the QQ plot showed an early deviation of identity line, which suggested a high proportion of true associations for a given $P$ value (Fig. 1). Therefore, the data suggest that the effect attributed to SNPs in T2D-related loci (FTO, MADD, CDKN2A-2B, LTA) might represent true associations.

\section{Predictive value of T2D-related variants}

In order to determine whether there was a joint effect of SNPs significantly associated with MM, we built a prediction model including gender and those nine SNPs showing overall significant associations with MM. After excluding the variables that did not remain significant in the model, the final model included six SNPs that increased the discriminatory ability to predict the risk of
MM when compared with a reference model including age and gender as covariates (AUC $=0.645$ 95\% CI 0.624-0.666; Table 3). The LR test showed that the model including genetic variants fitted better the data than the reference model, and that the difference in model fit between both models was statistically significant $\left(P=4.05 \times 10^{-06}\right)$. In addition, when we evaluated whether the model including genetic variants was consistent in predicting better the MM risk, we found that it showed an AUC value systematically higher than those of the 10000 randomized models (null distribution; $Z$ score $=6.42, P=6.81 \times 10^{-11}$; Supplementary Material), emphasizing the importance of considering genetic variants significantly associated with MM when building predictive models.

\section{Gender-specific associations with MM risk}

Interestingly, a gender-stratified analysis also revealed significant gender effect modifications for $A D A M 3 O_{\text {rs2641348 }}$ and $N O T C H 2_{\text {rs10923931 }}$ SNPs $\left(P_{\text {interaction }}\right.$ $=0.001$ and 0.0004 respectively). For $A D A M 30_{\mathrm{rs} 2641348 \mathrm{C}}$ and $\mathrm{NOTCH} 2_{\mathrm{rs} 10923931 \mathrm{~T}}$ alleles, a significantly reduced risk for the disease was observed in men (per-allele $\mathrm{OR}=0.71$, 95\% CI 0.54-0.94, $P=0.015$ and per-allele $\mathrm{OR}=0.66,95 \%$ CI $0.50-0.86, P=0.0019$, respectively) whereas a nonsignificant opposite effect was seen in women (per-allele $\mathrm{OR}=1.22,95 \% \mathrm{CI} 0.93-1.60$ and per-allele $\mathrm{OR}=1.15,95 \%$ CI $0.89-1.50$ respectively). A statistically significant heterogeneity, considering $P<0.05$ as a threshold, was also confirmed for these two SNPs $\left(P_{\mathrm{HET}}=0.0039\right.$ and $I^{2}=87.99 \%$ and $P_{\mathrm{HET}}=0.0024$ and $I^{2}=89.12 \%$, respectively), which supports the notion suggesting a role of gender in modulating the effect of these SNPs on $\mathrm{MM}$ risk. Although there was not a significant interaction with gender, we observed additional genderspecific associations for $W F S 1_{\mathrm{rs} 10010131}, T H A D A_{\mathrm{rs} 7578597}$, $E X T 2_{\text {rs1113132 }}$ and $G C K_{\text {rs } 1799884}$ SNPs according to dominant or recessive models of inheritance (Table 2 and Supplementary Material).

When we took account of multiple testing (with a threshold of $P=0.00022$ ), we found that the effect of the $I G F 1_{\mathrm{rs} 35767}$ variant was stronger in women than men with an association approaching significance with an increased risk of developing $\mathrm{MM}(\mathrm{OR}=3.13,95 \%$ CI 1.46-6.71, $P=0.0026$ vs $\mathrm{OR}=1.69,95 \%$ CI $0.94-3.02, P=0.079$ respectively). In addition, we found that the association of $\mathrm{NOTCH} 2_{\mathrm{rs} 10923931} \mathrm{SNP}$ with a decreased risk of MM in men was close to significance according to dominant and log-additive models $(\mathrm{OR}=0.66,95 \%$ CI $0.50-0.86$,

Published by Bioscientifica Ltd 


\section{要}

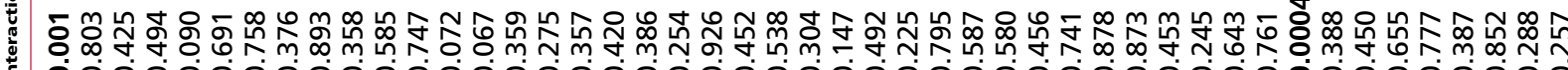

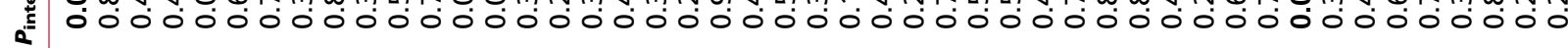

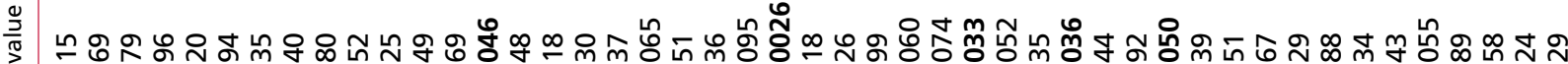
Q 00000000000000000000000000000000000000000000000

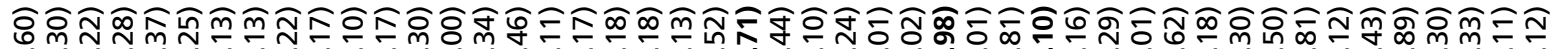
m-1 I 品 D下N

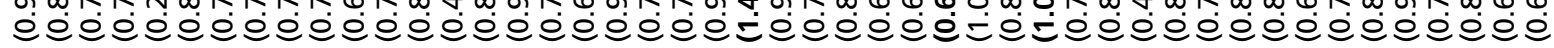

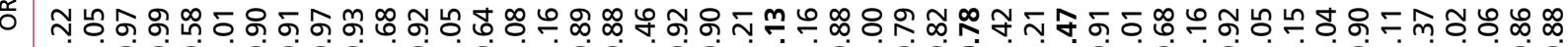

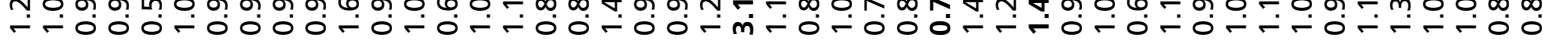

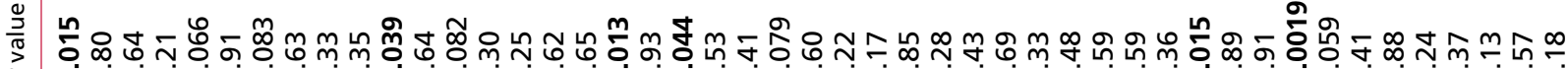
Q 00000000000000000000000000000000000000000000000

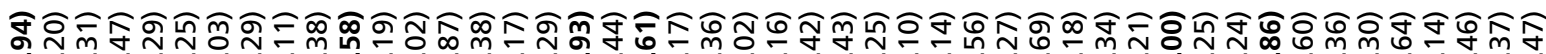

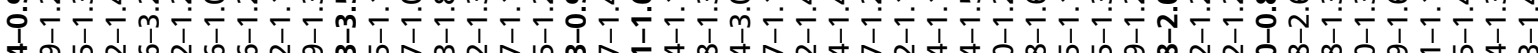

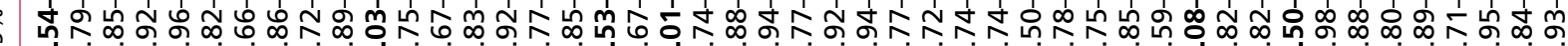

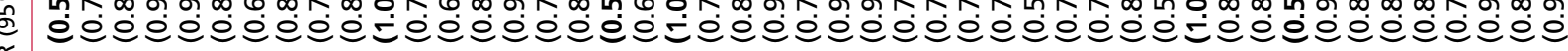

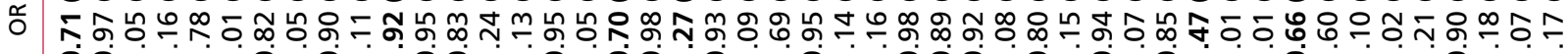

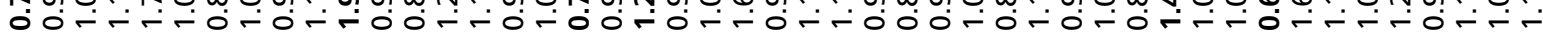

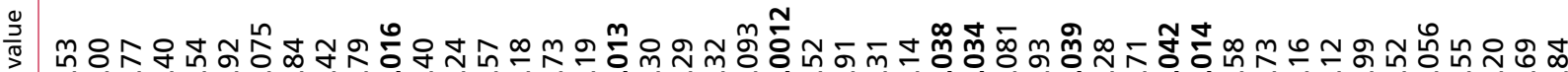
-1000000000000000000000000000000000000000000

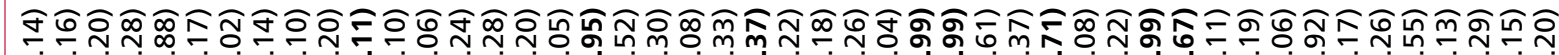

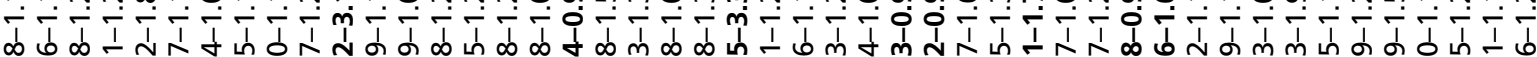

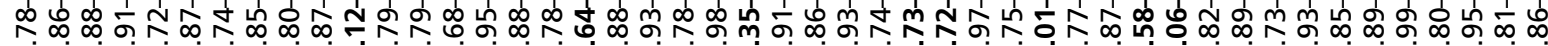

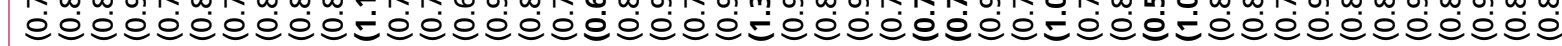

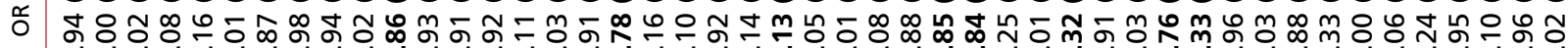

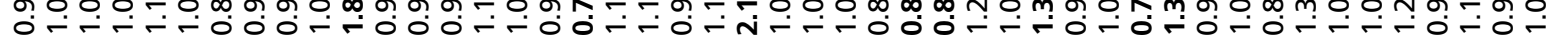
(1) 


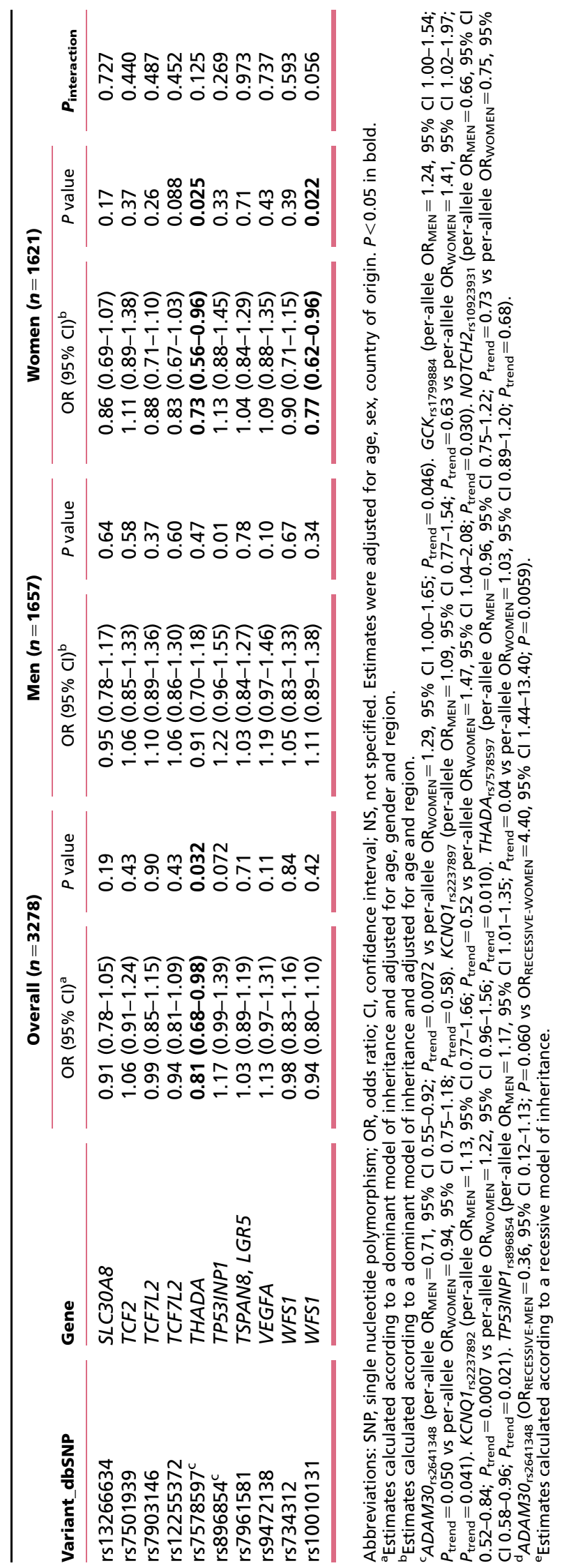

http://erc.endocrinology-journals.org DOI: $10.1530 /$ ERC-15-0029
$P=0.0019$ and $P_{\text {trend }}=0.0007$ ), which may suggest a gender-specific allele-dosage effect for this variant to modulate the disease risk $\left(P_{\text {interaction }}=0.0004\right.$; Table 2$)$. According to a log-additive model, we also found that the association of the $A D A M 3 O_{\text {rs } 2641348 C}$ allele with a decreased risk of MM in men showed a slight trend to be significant considering multiple testing ( $\mathrm{OR}=0.71,95 \%$ CI $0.55-0.92, P=0.0072$ ) whereas, according to a recessive model, the association of the $A D A M 3 O_{\mathrm{rs} 2641348 \mathrm{C} / \mathrm{C}}$ genotype was also close to survive multiple testing correction $(\mathrm{OR}=4.40,95 \%$ CI 1.44-13.40, $P=0.00059$; Table 2 and Supplementary Table 2 , see section on supplementary data given at the end of this article).

\section{Discussion}

In the present study, we report for the first time evidence of significant associations between GWAS-identified T2D genetic variants and $\mathrm{MM}$ risk. We found that carriers

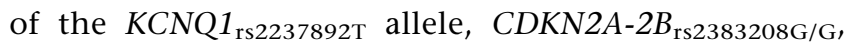
$I G F 1_{\mathrm{rs} 35767 \mathrm{~T} / \mathrm{T}}$ and $M A D D_{\mathrm{rs} 7944584 \mathrm{~T} / \mathrm{T}}$ genotypes were at increased risk of $\mathrm{MM}$, whereas those carrying the $K C N J 11_{\text {rs5215C }}, K C N J 11_{\text {rs5219T }}$ and $T H A D A_{\text {rs } 7578597 \mathrm{C}}$ alleles or the $F T O_{\mathrm{rs} 8050136 \mathrm{~A} / \mathrm{A}}$ and $L T A_{\mathrm{rs} 1041981 \mathrm{C} / \mathrm{C} \text { genotypes }}$ showed a decreased risk for the disease. The associations for the KCNQ1, CDKN2A-2B, IGF1, MADD, KCNJ11, and THADA gene variants with the risk of $\mathrm{MM}$ showed an opposite direction to those previously reported in the GWAS for T2D (i.e., the risk allele was the opposite for MM and T2DM), which points towards a non-diabetogenic mechanism underlying the effect of these variants to modulate the risk of the disease. In support of this hypothesis, several studies have suggested that, besides their influence on pancreatic function and insulin secretion through a wide variety of biological mechanisms, some of these genes may also act as tumour suppressor genes (Koh et al. 1995, Kim \& Sharpless 2006, Than et al. 2013) and have an impact in the modulation of cell survival (Butt et al. 1999, Ortega et al. 2002, Sharifi et al. 2013), differentiation (Pancewicz et al. 2010), proliferation (Grimberg 2003, Pancewicz et al. 2010) and apoptosis (LeRoith et al. 1995, Li et al. 2008, Pancewicz et al. 2010). Interestingly, a recent study demonstrated that T2D status was not implicated in the relationship between $H N F 1 B$ and JAZF1 variants and prostate cancer risk (Stevens et al. 2010), which is in line with our hypothesis suggesting that T2Drelated variants may determine the risk of $\mathrm{MM}$ through non-diabetogenic mechanisms.

When we took into account multiple testing corrections, only the association of the $I G F 1_{\mathrm{rs} 35767}$ promoter 


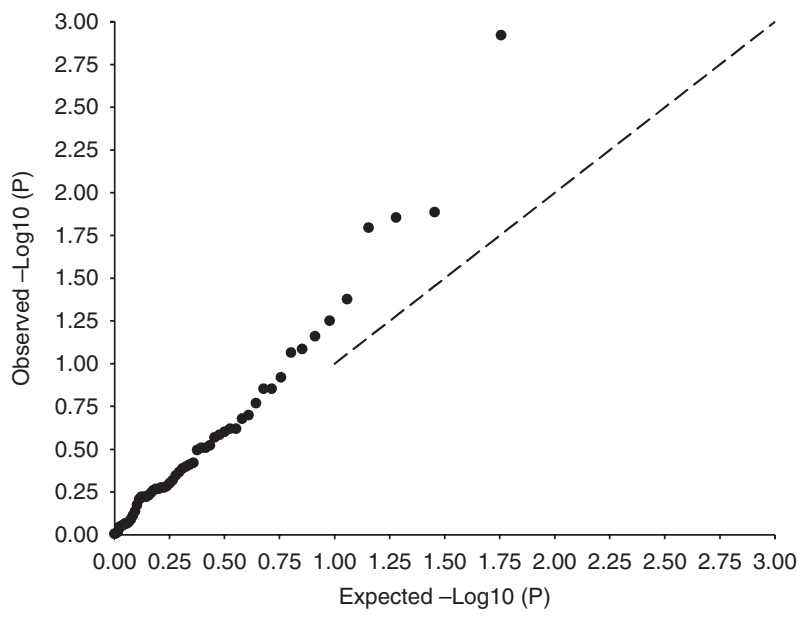

Figure 1

QQ plot used to evaluate the magnitude of observed associations of T2D-related variants with risk of MM. QQ plot was calculated assuming a recessive model of inheritance. Deviation from the expected distribution is observed above an expected $X^{2}$ of 0.75 . The $x$-axis is $-\log 10$ of the expected $P$ values (under a null hypothesis of no effects) whereas the $y$-axis is - $\log 10$ values of the actual $P$ values.

polymorphism with an increased risk of developing $\mathrm{MM}$ remained close to significance $(P=0.0012)$, which suggested that the IGF1 locus may play an important role in triggering cell proliferation in malignant plasma cells. In support of the hypothesis, it has been observed that IGF1 acts as a major growth factor in $\mathrm{MM}$ that, directly or in cooperation with other growth factors, induces MM cell growth and proliferation (Ferlin et al. 2000, Bommert et al. 2006, Sprynski et al. 2009) and can eventually lead to chemoresistance (Xu et al. 1997, Kuhn et al. 2012). Likewise, it has been also reported that treatment with metformin, an anti-diabetic drug that inhibits IGF1 signaling pathway, significantly reduces the risk of transformation from MGUS to symptomatic MM (American Society of Clinical Oncology Annual Meeting 2014; abstract 1532) and that constant use of this treatment may induce cell apoptosis (Rattan et al. 2012) and enhance the effectiveness of chemotherapeutic regimes in blood and solid cancers (Feng et al. 2011, Pan et al. 2012, Watson 2013). Interestingly, several authors have also reported that IGF1 and its analogues are associated with an increased death in patients with progressive MM (Standal et al. 2002, Chou et al. 2012, Wu et al. 2014), whereas the administration of metformin results in the reduction of deaths in patients with progressive disease (Wu et al. 2014).

In fact, Chen et al. (2013) recently demonstrated that the IGF1 $1_{\mathrm{rs} 35767} \mathrm{SNP}$ together with two neighbour SNPs constitutes a haplotype that efficiently regulates transcriptional activity (Chen et al. 2013). Similarly, several studies have consistently reported that carriers of the $I G F 1_{\mathrm{r} 335767 \mathrm{~T}}$ allele showed significantly higher levels of circulating IGF1 than those harbouring the WT allele (Mannino et al. 2013, Sesti et al. 2014) and that the presence of this variant is associated with an increased risk of developing several types of cancer (Ollberding et al. 2012, Qian et al. 2014).

Although it is tempting to speculate that the $I G F 1_{\mathrm{rs} 35767} \mathrm{SNP}$ may be responsible for the effect attributed to diabetes on the risk of MM, we believe that rather than

Table 3 Discriminative value AUC for models including T2D-related variants

\begin{tabular}{|c|c|c|c|}
\hline SNPs & $P$ value & OR 95\% Cl & AUC $95 \%$ Cl $^{\mathrm{ab}}$ \\
\hline \multicolumn{4}{|l|}{ Reference model ${ }^{c}$} \\
\hline Gender & 0.731 & $0.972(0.828-1.141)$ & \\
\hline Age & $<2.00 \times 10^{-16}$ & $1.036(1.030-1.042)$ & $0.629(0.607-0.650)^{\mathrm{e}}$ \\
\hline \multicolumn{4}{|c|}{ Predictive model built with six significant SNPs ${ }^{d}$} \\
\hline$I G F 1_{\text {rs35767 }}$ & 0.004 & $2.076(1.258-3.426)$ & \\
\hline$F T O_{\mathrm{rs} 8050136}$ & 0.002 & $0.723(0.586-0.892)$ & \\
\hline$M A D D_{\mathrm{rs} 7944584}$ & 0.094 & $1.218(0.967-1.535)$ & \\
\hline$P R C 1_{\mathrm{rs} 8042680}$ & 0.061 & $1.261(0.989-1.607)$ & \\
\hline KCNJ11 rs5215 & 0.027 & $0.832(0.706-0.980)$ & \\
\hline$K C N Q 1_{\text {rs2237892 }}$ & 0.008 & $1.468(1.106-1.950)$ & \\
\hline Gender & 0.776 & $1.024(0.871-1.204)$ & \\
\hline Age & $<2.00 \times 10^{-16}$ & $1.037(1.031-1.043)$ & $0.645(0.624-0.666)^{e f}$ \\
\hline
\end{tabular}

ancluding age and gender as variables never dropped from models.

${ }^{\mathrm{b}}$ Compared with a baseline model with $\mathrm{AUC}=0.5$.

Including age and gender as covariates.

dSNPs showing a significant association with MM $(P<0.05)$. After removing missing values, 2460 subjects were available for prediction capacity analysis. ${ }^{\mathrm{e}} \mathrm{A}$ LR test showed that the model including genetic variants fitted the data better than the reference model and that the difference in model fit between both models was statistically significant ( $-2 \log$ likelihood ratio test, $\mathrm{df}=6, P=4.05 \times 10^{-06}$ ). residual deviance (reference model): 3380.4 . residual deviance (significant SNPs model): 3345.2 .

${ }^{\dagger} A$ sort analysis revealed that this model showed an AUC value systematically higher than those observed in 10000 randomized models (null distribution; $Z$ score $=6.42, P=6.81 \times 10^{-11}$; Supplementary Material). 
acting separately to modulate the risk of the disease, this genetic variant acts along with additional variants within KCNQ1, CDKN2A-2B, MADD, KCNJ11, THADA, LTA and $F T O$ genes to modulate the disease risk. In order to test this hypothesis, we decided to evaluate the predictive value of T2D-related polymorphisms for prediction of MM using stepwise logistic and Cox regression analyses. Interestingly, we found that adding genetic factors to a model without covariates (including only age and gender) substantially improved the prediction of disease development. A predictive model including six SNPs significantly associated with $\mathrm{MM}$ in the single analysis showed an adjusted concordance statistic AUC of $64.5 \%$ for MM. The consistency of this result was confirmed through a randomization test that showed that none of the 10000 randomized models showed a higher AUC value than our 'original' model including six genetic variants, age and gender. The addition of genetic variants associated with $\mathrm{MM}$ at $P<0.10$ level did not improve the discriminatory ability to predict $\mathrm{MM}$, which pointed towards a joint contribution of IGF1, FTO, MADD, PRC1, KCNJ11 and KCNQ1 polymorphisms to predict the risk of the disease. Although the prediction capacity of these models could be considered relatively small when compared with a reference model, the relative absence of current diagnostic factors for MM suggest that the use of genetic variants could be a good option to improve the prediction of the disease risk.

The association of the non-diabetogenic alleles or genotypes for the polymorphisms within KCNQ1, CDKN2A-2B, MADD, KCNJ11, THADA and FTO genes with the risk of MM suggests that these genes, rather than acting through an insulin-dependent mechanism, may modulate the risk of MM by acting as tumour suppressor genes (Duro et al. 1995) or through mechanisms promoting cancer cell apoptosis (Rippe et al. 2003, Turner et al. 2013). In support of this idea, it has been recently reported that most of these genes are highly expressed in tumours and that genetic polymorphisms in these loci are also associated with cancer development (Sauroja et al. 2000, Cander et al. 2014) and tumour progression (Chen et al. 2009).

The association of $L T A_{\mathrm{rs} 1041981}$ SNP with a decreased risk of MM showed a similar direction to that observed in the GWAS for T2D ( $L T A_{\mathrm{rs} 1041981 \mathrm{~A}}$ as risk allele) suggests a diabetogenic effect of this SNP to modify the risk of MM. However, we could not dismiss the idea suggesting that observed association could be due to a different distribution of diabetics between MM cases and controls. Similarly, although the direction of the association for the $F T O_{\mathrm{rs} 8050136} \mathrm{SNP}$ with the risk of MM was opposite to the one observed in the GWAS for T2D, we could not rule out the possibility that the observed effect for this obesogenic SNP (Scuteri et al. 2007) could be due to significant differences in BMI between MM cases and controls. Further studies using well-characterized cohorts are needed to confirm these latter associations.

Although it was not the primary objective of this study, we also performed gender-stratified analysis to assess whether there was a gender effect modification of selected SNPs to modulate the risk of developing MM. Interestingly, we found a significant gender effect modification for ADAM3O rs2641348, $_{\text {, }}$ and NOTCH $2_{\text {rs10923931 }}$ SNPs, which suggested a gender-specific effect of these loci to modulate the risk of MM. We observed that, according to a logadditive model of inheritance, the association of the $\mathrm{NOTCH} 2_{\mathrm{rs} 10923931} \mathrm{SNP}$ with a decreased risk of MM in men and the association of $A D A M 3 O_{\mathrm{rs} 2641348 \mathrm{C} / \mathrm{C}}$ genotype with an increased risk of MM in women showed a marginal level of significance after correction for multiple testing. Recently, it has been demonstrated that NOTCH2 is highly expressed in MM cells and that it is a key regulator of MM pathogenesis (Colombo et al. 2013). In particular, it has been reported that the activation of the NOTCH2, which interacts with Wnt components, induces an exacerbated growth of MM cells and accelerated the course of the disease by promoting cancer stem cell self-renewal (Xu et al. 2012a) and resistance to chemotherapeutic agents (Xu et al. 2012b). Considering that $N O T C H 2_{\mathrm{rs} 10923931}$ and $A D A M 3 O_{\mathrm{rs} 2641348}$ are neighbour SNPs in strong linkage disequilibrium (Zeggini et al. 2008) and that they showed gender-specific associations with the risk of $\mathrm{MM}$, we hypothesize that NOTCH2-ADAM3O might represent a gender-specific susceptibility region for MM. In support of this idea, it has been reported that gender-specific variants within $\mathrm{NOTCH}$ and WNT signalling pathways, which are involved in determining cell proliferation and differentiation, may lead to important gender-specific differences in tumour recurrence and chemoresistance (Paez et al. 2014).

Our study has both strengths and weaknesses. The major strength is the large sample size. To our knowledge, this is the first study to evaluate the overall and genderspecific associations of T2D-related variants with the risk of developing $\mathrm{MM}$ and to assess their predictive value for MM. Although the influence of diabetogenic variants on the risk of the disease was expected to be very modest, our study was sufficiently powered to detect such small effects. Based on the genotype frequencies observed in our study cohort, we had $80 \%$ of power (dominant model) to detect an OR of 1.29 at $\alpha=0.00022$ (multiple testing threshold) for a polymorphism with a minor allele frequency of 0.25 . Although the gender-stratified analysis reduced the

Published by Bioscientifica Ltd. 
statistical power to detect effect of SNPs, we still had 80\% of power to detect ORs of 1.43 and 1.44 for men and women respectively. It is important to realise, however, that although the present study involves data on over 3334 individuals, the retrospective and multicentre study design places inevitable limitations on clinical data availability. T2D status and BMI were not available for a substantial subset of MM cases, which did not allow us to adjust our analyses for these variables and, consequently, to rule out the possibility that some of the reported associations could arise as a result of a different distribution of diabetics and/or obese subjects between MM cases and controls. Nonetheless, considering that most of the reported associations with MM risk showed a different direction to those previously published in the GWAS for T2D and given that most of these genes are not linked to obesity, we could not expect to find false positive associations due to these confounding factors.

In conclusion, our study indicate that T2D-related variants within IGF1, KCNJ11, CDKN2A-2B, MADD, THADA, LTA, FTO, ADAM3O and NOTCH2 genes may influence the risk of $\mathrm{MM}$ through insulin-independent mechanisms and that genotyping of specific T2D-related variants may be useful to improve the prediction of MM development. Additional work is needed to replicate our findings in independent and well-characterized populations and functional studies are also warranted to elucidate the biological mechanisms underlying the observed effects.

\section{Supplementary data}

This is linked to the online version of the paper at http://dx.doi.org/10.1530/ ERC-15-0029.

\section{Declaration of interest}

V Andersen is receiving compensation as a consultant for MSD (Merck) and Janssen. The rest of the authors have nothing to disclose.

\section{Funding}

This work was supported by grants from the FIBAO foundation (Granada, Spain) and the CRIS foundation against cancer, from the Cancer Network of Excellence (RD12/10 Red de Cáncer) and from the Instituto de Salud Carlos III (Madrid, Spain; PI12/02688).

\section{References}

Alexander DD, Mink PJ, Adami HO, Cole P, Mandel JS, Oken MM \& Trichopoulos D 2007 Multiple myeloma: a review of the epidemiologic literature. International Journal of Cancer 120 (Suppl 12) 40-61. (doi:10.1002/ijc.22718)
Altshuler D, Hirschhorn JN, Klannemark M, Lindgren CM, Vohl MC Nemesh J, Lane CR, Schaffner SF, Bolk S, Brewer C et al. 2000 The common PPAR $\gamma$ Pro12Ala polymorphism is associated with decreased risk of type 2 diabetes. Nature Genetics 26 76-80. (doi:10.1038/79839)

Badros A, Goloubeva O, Dalal JS, Can I, Thompson J, Rapoport AP, Heyman M, Akpek G \& Fenton RG 2007 Neurotoxicity of bortezomib therapy in multiple myeloma: a single-center experience and review of the literature. Cancer 110 1042-1049. (doi:10.1002/cncr.22921)

Bommert K, Bargou RC \& Stuhmer T 2006 Signalling and survival pathways in multiple myeloma. European Journal of Cancer 42 1574-1580. (doi:10.1016/j.ejca.2005.12.026)

Bouatia-Naji N, Rocheleau G, Van Lommel L, Lemaire K, Schuit F, Cavalcanti-Proença C, Marchand M, Hartikainen AL, Sovio U, De Graeve F et al. 2008 A polymorphism within the G6PC2 gene is associated with fasting plasma glucose levels. Science 320 1085-1088. (doi:10.1126/science.1156849)

Bouatia-Naji N, Bonnefond A, Cavalcanti-Proença C, Sparsø T, Holmkvist J, Marchand M, Delplanque J, Lobbens S, Rocheleau G, Durand E et al. 2009 A variant near MTNR1B is associated with increased fasting plasma glucose levels and type 2 diabetes risk. Nature Genetics 41 89-94. (doi:10.1038/ng.277)

Butt AJ, Firth SM \& Baxter RC 1999 The IGF axis and programmed cell death. Immunology and Cell Biology 77 256-262. (doi:10.1046/j.14401711.1999.00822.x)

Cander S, Karkucak M, Gul OO, Sag SO, Yakut T, Ersoy C, Tuncel E \& Erturk E 2014 Association between p16(CDKN2A) C540G polymorphism and tumor behavior in prolactinoma: a single-center study. Biomedical Reports 2 589-595. (doi:10.3892/br.2014.281)

Castillo JJ, Mull N, Reagan JL, Nemr S \& Mitri J 2012 Increased incidence of non-Hodgkin lymphoma, leukemia, and myeloma in patients with diabetes mellitus type 2: a meta-analysis of observational studies. Blood 119 4845-4850. (doi:10.1182/blood-2011-06-362830)

Chambers JC, Elliott P, Zabaneh D, Zhang W, Li Y, Froguel P, Balding D Scott J \& Kooner JS 2008 Common genetic variation near MC4R is associated with waist circumference and insulin resistance. Nature Genetics 40 716-718. (doi:10.1038/ng.156)

Chen WM, Erdos MR, Jackson AU, Saxena R, Sanna S, Silver KD, Timpson NJ, Hansen T, Orrù M, Grazia Piras M et al. 2008 Variations in the G6PC2/ABCB11 genomic region are associated with fasting glucose levels. Journal of Clinical Investigation 118 2620-2628. (doi:10.1172/JCI34566)

Chen J, Li D, Killary AM, Sen S, Amos CI, Evans DB, Abbruzzese JL \& Frazier ML 2009 Polymorphisms of p16, p27, p73, and MDM2 modulate response and survival of pancreatic cancer patients treated with preoperative chemoradiation. Annals of Surgical Oncology 16 431-439. (doi:10.1245/s10434-008-0220-8)

Chen HY, Huang W, Leung VH, Fung SL, Ma SL, Jiang H \& Tang NL 2013 Functional interaction between SNPs and microsatellite in the transcriptional regulation of insulin-like growth factor 1. Human Mutation 34 1289-1297. (doi:10.1002/humu.22363)

Cheng I, Caberto CP, Lum-Jones A, Seifried A, Wilkens LR, Schumacher FR, Monroe KR, Lim U, Tiirikainen M, Kolonel LN et al. 2011 Type 2 diabetes risk variants and colorectal cancer risk: the Multiethnic Cohort and PAGE studies. Gut 60 1703-1711. (doi:10.1136/gut.2011. 237727)

Chiu BC, Gapstur SM, Greenland P, Wang R \& Dyer A 2006 Body mass index, abnormal glucose metabolism, and mortality from hematopoietic cancer. Cancer Epidemiology, Biomarkers \& Prevention 15 2348-2354. (doi:10.1158/1055-9965.EPI-06-0007)

Chou YS, Yang CF, Chen HS, Yang SH, Yu YB, Hong YC, Liu CY, Gau JP, Liu JH, Chen PM et al. 2012 Pre-existing diabetes mellitus in patients with multiple myeloma. European Journal of Haematology 89 320-327. (doi:10.1111/j.1600-0609.2012.01828.x)

Colombo M, Mirandola L, Platonova N, Apicella L, Basile A, Figueroa AJ Cobos E, Chiriva-Internati M \& Chiaramonte R 2013 Notch-directed microenvironment reprogramming in myeloma: a single path to multiple outcomes. Leukemia 27 1009-1018. (doi:10.1038/leu.2013.6) 
Diabetes Genetics Initiative of Broad Institute of Harvard and MIT, Lund University, and Novartis Institutes of BioMedical Research , Saxena R, Voight BF, Lyssenko V, Burtt NP, de Bakker PI, Chen H, Roix JJ, Kathiresan S, Hirschhorn JN et al. 2007 Genome-wide association analysis identifies loci for type 2 diabetes and triglyceride levels. Science 316 1331-1336. (doi:10.1126/science.1142358)

Dupuis J, Langenberg C, Prokopenko I, Saxena R, Soranzo N, Jackson AU, Wheeler E, Glazer NL, Bouatia-Naji N, Gloyn AL et al. 2010 New genetic loci implicated in fasting glucose homeostasis and their impact on type 2 diabetes risk. Nature Genetics 42 105-116. (doi:10.1038/ng.520)

Duro D, Bernard O, Della Valle V, Berger R \& Larsen CJ 1995 A new type of p16INK4/MTS1 gene transcript expressed in B-cell malignancies. Oncogene 11 21-29.

Feng YH, Velazquez-Torres G, Gully C, Chen J, Lee MH \& Yeung SC 2011 The impact of type 2 diabetes and antidiabetic drugs on cancer cell growth. Journal of Cellular and Molecular Medicine 15 825-836. (doi:10.1111/j.1582-4934.2010.01083.x)

Ferlin M, Noraz N, Hertogh C, Brochier J, Taylor N \& Klein B 2000 Insulinlike growth factor induces the survival and proliferation of myeloma cells through an interleukin-6-independent transduction pathway. British Journal of Haematology 111 626-634. (doi:10.1046/j.1365-2141. 2000.02364.x)

Florez JC, Manning AK, Dupuis J, McAteer J, Irenze K, Gianniny L, Mirel DB, Fox CS, Cupples LA \& Meigs JB 2007 A 100K genome-wide association scan for diabetes and related traits in the Framingham Heart Study: replication and integration with other genome-wide datasets. Diabetes 56 3063-3074. (doi:10.2337/db07-0451)

Folsom AR, Pankow JS, Peacock JM, Bielinski SJ, Heiss G \& Boerwinkle E 2008 Variation in TCF7L2 and increased risk of colon cancer: the Atherosclerosis Risk in Communities (ARIC) Study. Diabetes Care 31 905-909. (doi:10.2337/dc07-2131)

Gloyn AL, Weedon MN, Owen KR, Turner MJ, Knight BA, Hitman G, Walker M, Levy JC, Sampson M, Halford S et al. 2003 Large-scale association studies of variants in genes encoding the pancreatic $\beta$-cell KATP channel subunits Kir6.2 (KCNJ11) and SUR1 (ABCC8) confirm that the KCNJ11 E23K variant is associated with type 2 diabetes. Diabetes 52 568-572. (doi:10.2337/diabetes.52.2.568)

Grant SF, Thorleifsson G, Reynisdottir I, Benediktsson R, Manolescu A, Sainz J, Helgason A, Stefansson H, Emilsson V, Helgadottir A et al. 2006 Variant of transcription factor 7-like 2 (TCF7L2) gene confers risk of type 2 diabetes. Nature Genetics 38 320-323. (doi:10.1038/ng1732)

Grarup N, Andersen G, Krarup NT, Albrechtsen A, Schmitz O, Jørgensen T, Borch-Johnsen K, Hansen T \& Pedersen O 2008 Association testing of novel type 2 diabetes risk alleles in the JAZF1, CDC123/CAMK1D, TSPAN8, THADA, ADAMTS9, and NOTCH2 loci with insulin release, insulin sensitivity, and obesity in a population-based sample of 4,516 glucose-tolerant middle-aged Danes. Diabetes 57 2534-2540. (doi:10.2337/db08-0436)

Grimberg A 2003 Mechanisms by which IGF-I may promote cancer. Cancer Biology \& Therapy 2 630-635. (doi:10.4161/cbt.2.6.678)

Gudmundsson J, Sulem P, Steinthorsdottir V, Bergthorsson JT, Thorleifsson G, Manolescu A, Rafnar T, Gudbjartsson D, Agnarsson BA, Baker A et al. 2007 Two variants on chromosome 17 confer prostate cancer risk, and the one in TCF2 protects against type 2 diabetes. Nature Genetics 39 977-983. (doi:10.1038/ng2062)

Hamid YH, Urhammer SA, Glümer C, Borch-Johnsen K, Jørgensen T, Hansen T \& Pedersen O 2005 The common T60N polymorphism of the lymphotoxin- $\alpha$ gene is associated with type 2 diabetes and other phenotypes of the metabolic syndrome. Diabetologia $48445-451$. (doi:10.1007/s00125-004-1659-1)

International Myeloma Working Group 2003 Criteria for the classification of monoclonal gammopathies, multiple myeloma and related disorders: a report of the International Myeloma Working Group. British Journal of Haematology 121 749-757. (doi:10.1046/j.1365-2141.2003.04355.x)

Khan AE, Gallo V, Linseisen J, Kaaks R, Rohrmann S, Raaschou-Nielsen O, Tjonneland A, Johnsen HE, Overvad K, Bergmann MM et al. 2008
Diabetes and the risk of non-Hodgkin's lymphoma and multiple myeloma in the European Prospective Investigation into Cancer and Nutrition. Haematologica 93 842-850. (doi:10.3324/haematol.12297)

Kim WY \& Sharpless NE 2006 The regulation of INK4/ARF in cancer and aging. Cell 127 265-275. (doi:10.1016/j.cell.2006.10.003)

Koh J, Enders GH, Dynlacht BD \& Harlow E 1995 Tumour-derived p16 alleles encoding proteins defective in cell-cycle inhibition. Nature $\mathbf{3 7 5}$ 506-510. (doi:10.1038/375506a0)

Kuhn DJ, Berkova Z, Jones RJ, Woessner R, Bjorklund CC, Ma W, Davis RE, Lin P, Wang H, Madden TL et al. 2012 Targeting the insulin-like growth factor-1 receptor to overcome bortezomib resistance in preclinical models of multiple myeloma. Blood 120 3260-3270. (doi:10.1182/ blood-2011-10-386789)

Kumar SK, Dispenzieri A, Lacy MQ, Gertz MA, Buadi FK, Pandey S, Kapoor P, Dingli D, Hayman SR, Leung N et al. 2014 Continued improvement in survival in multiple myeloma: changes in early mortality and outcomes in older patients. Leukemia 28 1122-1128. (doi:10.1038/leu.2013.313)

Lau J, Ioannidis JP \& Schmid CH 1997 Quantitative synthesis in systematic reviews. Annals of Internal Medicine 127 820-826. (doi:10.7326/00034819-127-9-199711010-00008)

LeRoith D, Werner H, Beitner-Johnson D \& Roberts CT Jr 1995 Molecular and cellular aspects of the insulin-like growth factor I receptor. Endocrine Reviews 16 143-163. (doi:10.1210/edrv-16-2-143)

Li H, Wang J, Mor G \& Sklar J 2008 A neoplastic gene fusion mimics transsplicing of RNAs in normal human cells. Science 321 1357-1361. (doi:10.1126/science.1156725)

Lope V, Perez-Gomez B, Aragones N, Lopez-Abente G, Gustavsson P, Plato N, Zock JP \& Pollan M 2008 Occupation, exposure to chemicals, sensitizing agents, and risk of multiple myeloma in Sweden. Cancer Epidemiology, Biomarkers \& Prevention 17 3123-3127. (doi:10.1158/ 1055-9965.EPI-08-0343)

Lyssenko V, Nagorny CL, Erdos MR, Wierup N, Jonsson A, Spégel P, Bugliani M, Saxena R, Fex M, Pulizzi N et al. 2009 Common variant in MTNR1B associated with increased risk of type 2 diabetes and impaired early insulin secretion. Nature Genetics 41 82-88. (doi:10.1038/ng.288)

Ma RC, So WY, Tam CH, Luk AO, Ho JS, Wang Y, Lam VK, Lee HM, Kong AP, Tong PC et al. 2014 Genetic variants for type 2 diabetes and new-onset cancer in Chinese with type 2 diabetes. Diabetes Research and Clinical Practice 103 328-337. (doi:10.1016/j.diabres.2013.12.016)

Mannino GC, Greco A, De Lorenzo C, Andreozzi F, Marini MA, Perticone F \& Sesti G 2013 A fasting insulin-raising allele at IGF1 locus is associated with circulating levels of IGF-1 and insulin sensitivity. PLOS ONE $\mathbf{8}$ e85483. (doi:10.1371/journal.pone.0085483)

Martino A, Sainz J, Buda G, Jamroziak K, Reis RM, Garcia-Sanz R, Jurado M, Rios R, Szemraj-Rogucka Z, Marques H et al. 2012 Genetics and molecular epidemiology of multiple myeloma: the rationale for the IMMEnSE consortium (review). International Journal of Oncology $\mathbf{4 0}$ 625-638. (doi:10.3892/ijo.2011.1284)

Mohlke KL, Boehnke M \& Abecasis GR 2008 Metabolic and cardiovascular traits: an abundance of recently identified common genetic variants. Human Molecular Genetics 17 R102-R108. (doi:10.1093/hmg/ddn275)

Morgan GJ, Walker BA \& Davies FE 2012 The genetic architecture of multiple myeloma. Nature Reviews. Cancer 12 335-348. (doi:10.1038/ nrc3257)

Nielsen T, Sparsø T, Grarup N, Jørgensen T, Pisinger C, Witte DR, Diabetes Genetics Replication and Meta-analysis (DIAGRAM) Consortium, Hansen T \& Pedersen O 2011 Type 2 diabetes risk allele near CENTD2 is associated with decreased glucose-stimulated insulin release. Diabetologia 54 1052-1056. (doi:10.1007/s00125-011-2054-3)

Nyholt DR 2004 A simple correction for multiple testing for singlenucleotide polymorphisms in linkage disequilibrium with each other. American Journal of Human Genetics 74 765-769. (doi:10.1086/383251)

Ollberding NJ, Cheng I, Wilkens LR, Henderson BE, Pollak MN, Kolonel LN \& Le Marchand L 2012 Genetic variants, prediagnostic circulating levels of insulin-like growth factors, insulin, and glucose and the risk of colorectal cancer: the Multiethnic Cohort study. Cancer 
Epidemiology, Biomarkers \& Prevention 21 810-820. (doi:10.1158/ 1055-9965.EPI-11-1105)

Ortega S, Malumbres M \& Barbacid M 2002 Cyclin D-dependent kinases, INK4 inhibitors and cancer. Biochimica et Biophysica Acta 1602 73-87.

Paez D, Gerger A, Zhang W, Yang D, Labonte MJ, Benhanim L, Kahn M, Lenz F, Lenz C, Ning Y et al. 2014 Association of common gene variants in the WNT/ $\beta$-catenin pathway with colon cancer recurrence. Pharmacogenomics Journal 14 142-150. (doi:10.1038/tpj.2013.20)

Pan J, Chen C, Jin Y, Fuentes-Mattei E, Velazquez-Tores G, Benito JM, Konopleva M, Andreeff M, Lee MH \& Yeung SC 2012 Differential impact of structurally different anti-diabetic drugs on proliferation and chemosensitivity of acute lymphoblastic leukemia cells. Cell Cycle $\mathbf{1 1}$ 2314-2326. (doi:10.4161/cc.20770)

Pancewicz J, Taylor JM, Datta A, Baydoun HH, Waldmann TA, Hermine O $\&$ Nicot C 2010 Notch signaling contributes to proliferation and tumor formation of human T-cell leukemia virus type 1-associated adult T-cell leukemia. PNAS 107 16619-16624. (doi:10.1073/pnas.1010722107)

Pechlivanis S, Wagner K, Chang-Claude J, Hoffmeister M, Brenner H \& Forsti A 2007 Polymorphisms in the insulin like growth factor 1 and IGF binding protein 3 genes and risk of colorectal cancer. Cancer Detection and Prevention 31 408-416. (doi:10.1016/j.cdp.2007.10.001)

Prokopenko I, Langenberg C, Florez JC, Saxena R, Soranzo N, Thorleifsson G, Loos RJ, Manning AK, Jackson AU, Aulchenko Y et al. 2009 Variants in MTNR1B influence fasting glucose levels. Nature Genetics 41 77-81. (doi:10.1038/ng.290)

Qi L, Cornelis MC, Kraft P, Stanya KJ, Linda Kao WH, Pankow JS, Dupuis J, Florez JC, Fox CS, Paré G et al. 2010 Genetic variants at 2q24 are associated with susceptibility to type 2 diabetes. Human Molecular Genetics 19 2706-2715. (doi:10.1093/hmg/ddq156)

Qian J, Zhou H, Chen J, Ding Q, Cao Q, Qin C, Shao P, Li P, Cai H, Meng X et al. 2014 Genetic polymorphisms in IGF-I and IGFBP-3 are associated with prostate cancer in the Chinese population. PLOS ONE 9 e85609. (doi:10.1371/journal.pone.0085609)

Rattan R, Ali Fehmi R \& Munkarah A 2012 Metformin: an emerging new therapeutic option for targeting cancer stem cells and metastasis. Journal of Oncology 2012 928127. (doi:10.1155/2012/928127)

Richardson PG, Briemberg H, Jagannath S, Wen PY, Barlogie B, Berenson J, Singhal S, Siegel DS, Irwin D, Schuster M et al. 2006 Frequency, characteristics, and reversibility of peripheral neuropathy during treatment of advanced multiple myeloma with bortezomib. Journal of Clinical Oncology 24 3113-3120. (doi:10.1200/JCO.2005.04.7779)

Richardson PG, Sonneveld P, Schuster MW, Stadtmauer EA, Facon T, Harousseau JL, Ben-Yehuda D, Lonial S, Goldschmidt H, Reece D et al. 2009 Reversibility of symptomatic peripheral neuropathy with bortezomib in the phase III APEX trial in relapsed multiple myeloma: impact of a dose-modification guideline. British Journal of Haematology 144 895-903. (doi:10.1111/j.1365-2141.2008.07573.x)

Rippe V, Drieschner N, Meiboom M, Murua Escobar H, Bonk U, Belge G \& Bullerdiek J 2003 Identification of a gene rearranged by 2 p21 aberrations in thyroid adenomas. Oncogene 22 6111-6114. (doi:10.1038/sj.onc.1206867)

Rung J, Cauchi S, Albrechtsen A, Shen L, Rocheleau G, Cavalcanti-Proença C, Bacot F, Balkau B, Belisle A, Borch-Johnsen K et al. 2009 Genetic variant near IRS1 is associated with type 2 diabetes, insulin resistance and hyperinsulinemia. Nature Genetics 41 1110-1115. (doi:10.1038/ng.443)

Sainz J, Rudolph A, Hoffmeister M, Frank B, Brenner H, Chang-Claude J, Hemminki K \& Forsti A 2012 Effect of type 2 diabetes predisposing genetic variants on colorectal cancer risk. Journal of Clinical Endocrinology and Metabolism 97 E845-E851. (doi:10.1210/jc.2011-2565)

Sandhu MS, Weedon MN, Fawcett KA, Wasson J, Debenham SL, Daly A, Lango H, Frayling TM, Neumann RJ, Sherva R et al. 2007 Common variants in WFS1 confer risk of type 2 diabetes. Nature Genetics 39 951-953. (doi:10.1038/ng2067)

Sauroja I, Smeds J, Vlaykova T, Kumar R, Talve L, Hahka-Kemppinen M, Punnonen K, Jansen CT, Hemminki K \& Pyrhonen S 2000 Analysis of $\mathrm{G}(1) / \mathrm{S}$ checkpoint regulators in metastatic melanoma. Genes,
Chromosomes \& Cancer 28 404-414. (doi:10.1002/10982264(200008)28:4<404::AID-GCC6>3.0.CO;2-P)

Saxena R, Hivert MF, Langenberg C, Tanaka T, Pankow JS, Vollenweider P, Lyssenko V, Bouatia-Naji N, Dupuis J, Jackson AU et al. 2010 Genetic variation in GIPR influences the glucose and insulin responses to an oral glucose challenge. Nature Genetics 42 142-148. (doi:10.1038/ ng.521)

Scott LJ, Bonnycastle LL, Willer CJ, Sprau AG, Jackson AU, Narisu N, Duren WL, Chines PS, Stringham HM, Erdos MR et al. 2006 Association of transcription factor 7-like 2 (TCF7L2) variants with type 2 diabetes in a Finnish sample. Diabetes 55 2649-2653. (doi:10.2337/db06-0341)

Scott LJ, Mohlke KL, Bonnycastle LL, Willer CJ, Li Y, Duren WL, Erdos MR, Stringham HM, Chines PS, Jackson AU et al. 2007 A genome-wide association study of type 2 diabetes in Finns detects multiple susceptibility variants. Science 316 1341-1345. (doi:10.1126/science. 1142382)

Scuteri A, Sanna S, Chen WM, Uda M, Albai G, Strait J, Najjar S, Nagaraja R, Orru M, Usala G et al. 2007 Genome-wide association scan shows genetic variants in the FTO gene are associated with obesity-related traits. PLoS Genetics 3 e115. (doi:10.1371/journal.pgen.0030115)

Sesti G, Mannino GC, Andreozzi F, Greco A, Perticone M, Sciacqua A, Marini MA \& Perticone F 2014 A polymorphism at IGF1 locus is associated with carotid intima media thickness and endotheliumdependent vasodilatation. Atherosclerosis 232 25-30. (doi:10.1016/ j.atherosclerosis.2013.10.024)

Sharifi S, Daghighi S, Motazacker MM, Badlou B, Sanjabi B, Akbarkhanzadeh A, Rowshani AT, Laurent S, Peppelenbosch MP \& Rezaee F 2013 Superparamagnetic iron oxide nanoparticles alter expression of obesity and T2D-associated risk genes in human adipocytes. Scientific Reports 3 2173. (doi:10.1038/srep02173)

Shu XO, Long J, Cai Q, Qi L, Xiang YB, Cho YS, Tai ES, Li X, Lin X, Chow WH et al. 2010 Identification of new genetic risk variants for type 2 diabetes. PLoS Genetics 6 e1001127. (doi:10.1371/journal.pgen.1001127)

Sladek R, Rocheleau G, Rung J, Dina C, Shen L, Serre D, Boutin P, Vincent D, Belisle A, Hadjadj S et al. 2007 A genome-wide association study identifies novel risk loci for type 2 diabetes. Nature 445 881-885. (doi:10.1038/nature05616)

Sprynski AC, Hose D, Caillot L, Reme T, Shaughnessy JD Jr, Barlogie B, Seckinger A, Moreaux J, Hundemer M, Jourdan M et al. 2009 The role of IGF-1 as a major growth factor for myeloma cell lines and the prognostic relevance of the expression of its receptor. Blood $\mathbf{1 1 3}$ 4614-4626. (doi:10.1182/blood-2008-07-170464)

Standal T, Borset M, Lenhoff S, Wisloff F, Stordal B, Sundan A, Waage A \& Seidel C 2002 Serum insulinlike growth factor is not elevated in patients with multiple myeloma but is still a prognostic factor. Blood 100 3925-3929. (doi:10.1182/blood-2002-05-1406)

Steinthorsdottir V, Thorleifsson G, Reynisdottir I, Benediktsson R, Jonsdottir T, Walters GB, Styrkarsdottir U, Gretarsdottir S, Emilsson V, Ghosh S et al. 2007 A variant in CDKAL1 influences insulin response and risk of type 2 diabetes. Nature Genetics 39 770-775. (doi:10.1038/ ng2043)

Stevens VL, Ahn J, Sun J, Jacobs EJ, Moore SC, Patel AV, Berndt SI, Albanes D $\&$ Hayes RB 2010 HNF1B and JAZF1 genes, diabetes, and prostate cancer risk. Prostate 70 601-607. (doi:10.1002/pros.21094)

Takeuchi F, Serizawa M, Yamamoto K, Fujisawa T, Nakashima E, Ohnaka K, Ikegami H, Sugiyama T, Katsuya T, Miyagishi M et al. 2009 Confirmation of multiple risk Loci and genetic impacts by a genomewide association study of type 2 diabetes in the Japanese population. Diabetes 58 1690-1699. (doi:10.2337/db08-1494)

Tang Y, Han X, Sun X, Lv C, Zhang X, Guo W, Ren Q, Luo Y, Zhang X, Zhou X et al. 2013 Association study of a common variant near IRS1 with type 2 diabetes mellitus in Chinese Han population. Endocrine $\mathbf{4 3}$ 84-91. (doi:10.1007/s12020-012-9693-0)

Than BL, Goos JA, Sarver AL, O'Sullivan MG, Rod A, Starr TK, Fijneman RJ, Meijer GA, Zhao L, Zhang Y et al. 2013 The role of KCNQ1 in mouse and

Published by Bioscientifica Ltd. 
human gastrointestinal cancers. Oncogene 33 3861-3868. (doi:10.1038/ onc.2013.350)

Tsai FJ, Yang CF, Chen CC, Chuang LM, Lu CH, Chang CT, Wang TY, Chen RH, Shiu CF, Liu YM et al. 2010 A genome-wide association study identifies susceptibility variants for type 2 diabetes in Han Chinese. PLoS Genetics 6 e1000847. (doi:10.1371/journal.pgen.1000847)

Turner A, Li LC, Pilli T, Qian L, Wiley EL, Setty S, Christov K, Ganesh L, Maker AV, Li P et al. 2013 MADD knock-down enhances doxorubicin and TRAIL induced apoptosis in breast cancer cells. PLoS ONE $\mathbf{8}$ e56817. (doi:10.1371/journal.pone.0056817)

Unoki H, Takahashi A, Kawaguchi T, Hara K, Horikoshi M, Andersen G, Ng DP, Holmkvist J, Borch-Johnsen K, Jørgensen T et al. 2008 SNPs in KCNQ1 are associated with susceptibility to type 2 diabetes in East Asian and European populations. Nature Genetics 40 1098-1102. (doi:10.1038/ng.208)

Voight BF, Scott LJ, Steinthorsdottir V, Morris AP, Dina C, Welch RP, Zeggini E, Huth C, Aulchenko YS, Thorleifsson G et al. 2010 Twelve type 2 diabetes susceptibility loci identified through large-scale association analysis. Nature Genetics 42 579-589. (doi:10.1038/ng.609)

Wallin A \& Larsson SC 2011 Body mass index and risk of multiple myeloma: a meta-analysis of prospective studies. European Journal of Cancer 47 1606-1615. (doi:10.1016/j.ejca.2011.01.020)

Watson J 2013 Oxidants, antioxidants and the current incurability of metastatic cancers. Open Biology 3 120144. (doi:10.1098/rsob.120144)

Wellcome Trust Case Control C 2007 Genome-wide association study of 14,000 cases of seven common diseases and 3,000 shared controls. Nature 447 661-678. (doi:10.1038/nature05911)

Willer CJ, Bonnycastle LL, Conneely KN, Duren WL, Jackson AU, Scott LJ, Narisu N, Chines PS, Skol A, Stringham HM et al. 2007 Screening of 134 single nucleotide polymorphisms (SNPs) previously associated with type 2 diabetes replicates association with 12 SNPs in nine genes. Diabetes 56 256-264. (doi:10.2337/db06-0461)

Wu W, Merriman K, Nabaah A, Seval N, Seval D, Lin H, Wang M, Qazilbash MH, Baladandayuthapani V, Berry D et al. 2014 The association of diabetes and anti-diabetic medications with clinical outcomes in multiple myeloma. British Journal of Cancer 111 628-636. (doi:10.1038/bjc.2014.307)

Xu F, Gardner A, Tu Y, Michl P, Prager D \& Lichtenstein A 1997 Multiple myeloma cells are protected against dexamethasone-induced apoptosis by insulin-like growth factors. British Journal of Haematology $\mathbf{9 7}$ 429-440. (doi:10.1046/j.1365-2141.1997.592708.x)

Xu D, Hu J, Xu S, De Bruyne E, Menu E, Van Camp B, Vanderkerken K \& Van Valckenborgh E 2012a Dll1/Notch activation accelerates multiple myeloma disease development by promoting CD138 + MM-cell proliferation. Leukemia 26 1402-1405. (doi:10.1038/leu.2011.332)

Xu D, Hu J, De Bruyne E, Menu E, Schots R, Vanderkerken K \& Van Valckenborgh E $2012 b$ Dll1/Notch activation contributes to bortezomib resistance by upregulating CYP1A1 in multiple myeloma. Biochemical and Biophysical Research Communications 428 518-524. (doi:10.1016/j.bbrc.2012.10.071)

Xu CX, Zhu HH \& Zhu YM 2014 Diabetes and cancer: associations, mechanisms, and implications for medical practice. World Journal of Diabetes 5 372-380. (doi:10.4239/wjd.v5.i3.372)

Yamauchi T, Hara K, Maeda S, Yasuda K, Takahashi A, Horikoshi M, Nakamura M, Fujita H, Grarup N, Cauchi S et al. 2010 A genome-wide association study in the Japanese population identifies susceptibility loci for type 2 diabetes at UBE2E2 and C2CD4A-C2CD4B. Nature Genetics 42 864-868. (doi:10.1038/ng.660)

Yasuda K, Miyake K, Horikawa Y, Hara K, Osawa H, Furuta H, Hirota Y, Mori H, Jonsson A, Sato Y et al. 2008 Variants in KCNQ1 are associated with susceptibility to type 2 diabetes mellitus. Nature Genetics $\mathbf{4 0}$ 1092-1097. (doi:10.1038/ng.207)

Zeggini E, Weedon MN, Lindgren CM, Frayling TM, Elliott KS, Lango H, Timpson NJ, Perry JR, Rayner NW, Freathy RM et al. 2007 Replication of genome-wide association signals in UK samples reveals risk loci for type 2 diabetes. Science 316 1336-1341. (doi:10.1126/science.1142364)

Zeggini E, Scott LJ, Saxena R, Voight BF, Marchini JL, Hu T, de Bakker PI, Abecasis GR, Almgren P, Andersen G et al. 2008 Meta-analysis of genome-wide association data and large-scale replication identifies additional susceptibility loci for type 2 diabetes. Nature Genetics $\mathbf{4 0}$ 638-645. (doi:10.1038/ng.120)

Received in final form 7 May 2015

Accepted 15 May 2015
(C) 2015 Society for Endocrinology Printed in Great Britain 